\title{
ECONOMIC CRISIS OF PAKISTAN AND ITS IMPACT ON ECONOMY OF PAKISTAN
}

Dr.Asif Ali Shah

Controller of Examination Shah Abdul latif University Khairpur Mirs

Faiz Muhammad Shaikh

Assistant Professor-SZABAC-Dokri- Larkana-Sindh-Pakistan

Muhammad Munir Ahmadani

Associate Professor Scahal College of Commerce Hyderabad

\begin{abstract}
:
This research investigates the Economic Crisis Of Pakistan And Its Impact On Economy Of Pakistan . Data were collected from various secondary sources, and data were analyzed by using SPSS-21 software. It was revealed that Pakistan is one of those developing countries which are facing through the economic problems which are hindering the success and the growth of the country. There are so many economic problems in Pakistan which are getting threatening and devastating day by day and if they are remained unattended than the conditions might even get to worse. Data were collected from various secondary sources. It was revealed Corruption is the prime reason behind the economical unstableness, Corruption has spread into the world and has ruined the economy. It is found in government as well as private sector also. Due to corruption, illiterate and dishonest workers come forward and cause industrial backwardness. Poor Social Sector Including Health, Safe Drinking Water, Sanitation etc.
\end{abstract}

\section{Council for Innovative Research}

Peer Review Research Publishing System

\section{Journal: International Journal Of Management \& Information Technology}

Vol . 11, No 1

editorsijmit@gmail.com

www.ijmit.com 
Introduction: Economy of any state is exceptionally urgent and it verifies that how stable and how fortify the state is. So it is all that much critical for ever nation to ensure that the economy of the state is steady and is sufficiently solid to experience the high points and low points in the nation inside and remotely. There are such a large number of Economic components which have made the financial emergency a standout amongst the most undermining issues in Pakistan raced to achievement and with their appropriate arrangements through which these issues can be determined.

\section{Writing Review}

This paper is a piece of a progression of discourse papers that have been readied by the Dr Ejaz Hussain is PhD in Political Science and functions as associate educator at IQRA University, Islamabad and Shah Faisal Afridi is an expert agent and CEO of Ruba SEZ Group. He got his formal instruction from Stamford College, Singapore.

The Working Papers consider perspectives based proficient examination of the creators. The discourse paper arrangement gives foundation data on Economic Crisis of Pakistan which is concentrating on major monetary issues which raises the Social issues like neediness, Illiteracy rate and so on. Since numerous Papers on the wellsprings of Economic emergencies highlight the significance of sharp vacillations in Country.

This paper quickly audits the significant effect on Pakistan Economy and its Industries. It likewise incorporates with is Conclusion and a few Suggestions to determine these sort of issues and to develop the Productivity of our Country.

\section{Financial Crisis of Pakistan}

Monetary Crisis, A circumstance in which the economy of a nation encounters a sudden downturn brought on by a budgetary emergency. An economy confronting a financial emergency will in all likelihood encounter a Falling GDP, a becoming scarce of Liquidity and Rising/Falling Prices because of Inflation/Deflation.

Economy of any state is exceptionally urgent and it confirms that how stable and how reinforce the state is. So it is all that much critical for each nation to ensure that the economy of the state is steady and is sufficiently solid to experience the good and bad times in the nation inside and remotely. Pakistan is one of the nations which have seen such a variety of varieties in the economy of the state.

What's more, in Today's Scenario Pakistan's Economy is in descending. Expansion is at 25\% (Food Inflation half), remote stores are falling and the Government is in risk of defaulting on its Foreign Debt. The Global Financial Crisis just debilitates to Pakistan's Economics troubles. Pakistan is viewing Foreign Investors. Feeble Governance has added to developing Economic inconveniences and Regional flimsiness.

There are such a variety of variables which have made the monetary emergency in the

\section{Nation rushed to achievement:}

\section{$>\quad$ Terrorism}

Is on the highest priority on the rundown, as Pakistan is confronting issues of terrorism for such quite a while now and confronting the religious fanaticism and the ruthless exercises of Taliban and different offices. This element has completely dispensed with the worldwide interest in the nation, so the trading of outside cash is being ceased. Suicide Attacks in the Industrial Cities dread among individuals, Disinvestment and most extreme Outflow of Capital.

\section{$>\quad$ Power emergency and load shedding}

Power emergency and load shedding of all the fundamental assets including power, Gas and petroleum, water has obstructed the handling units and constrained the general population to either close down their delivering units or even take those units out of the nation to the neighboring nations. It is influencing the mechanical creation in the nation. This has again punched the economy of the nation in unpleasant way.

\section{$>\quad$ Political flimsiness}

Is additionally assuming its part in making the states of economy much more terrible, all things considered variety in political and representing bodies, defilement, and nonstop thus incredible change and corrections in the approach of exchanging and delivering has been persistently making obstacles in the method for advancement and achievement of the economy.

\section{$>\quad$ Natural Disastrous}

Pakistan's $75 \%$ of the aggregate economy is specifically connected with the horticultural preparations; in such a situation tragically Pakistan has being hit with a few characteristic unfortunate including substantial flooding and quakes. Such catastrophes have demolished and crushed immense measure of developing terrains which has at last left numerous agriculturists powerless and sad. 


\section{Lack of Tourism}

Absence of tourism is additionally a reason for the declining in economy. Northern zones of Pakistan have been a position of extraordinary vacation spot. The wonderful slopes, the lavish green valleys, shining lakes and streaming waterfalls brought numerous a traveler from everywhere throughout the world to Pakistan. This added to remote trade. Pakistan as a risky and hazardous nation. Its poor lawfulness circumstance has frightened the traveler and consequently Northern ranges no more get numerous vacationers.

\section{$\gg \quad$ Lack of Technical Know-how}

There is absence of specialized and gifted laborers in the nation because of high rate of lack of education. Proficiency of work is low because of utilization of in reverse innovation. It is likewise a fundamental driver of modern backwardness.

\section{$>\quad$ Inflation}

Rising costs are harming numerous businesses .It is ascend underway expenses, which prompts an expansion in the cost of the last item. For instance, if crude materials increment in cost, this prompts the expense of generation expanding.

\section{$>\quad$ We Export low And Import High}

Absence of force took after by decrease underway is the fundamental driver of declining fare which is a noteworthy conservative issue around the world. The generation can't even satisfy the requests and tint to decrease in a bad position, the world economy is enduring awesome issues.

\section{$>\quad$ Poorly Managed Tax System}

Just salaried persons pay standard assessment, while the significant segments discover safe way through defilement. Agribusiness charge can't be forced because of primitive in strategy making. Expense is really the blood sucked by the Government as Money on the grounds that it is not utilize appropriately for the Welfare of Pakistan.

\section{$>\quad$ Lack of Industrial Research}

Research work for mechanical segment is not acceptable because of absence of specialized training and lack of innovative colleges in the nation. Change underway and diminishment in expense of creation is outlandish because of absence of examination.

\section{$\triangleright \quad$ Loss in Business}

The poor conservative framework influences the business severely. Individuals everywhere throughout the world are confronting genuine misfortunes in business. In Pakistan sugar, bond and shoe industry is on its destruction while material industry is breathing its last. Remote financial specialists are not prepared to setup their organizations in Pakistan.

\section{SOCIAL ISSUES OF PAKISTAN}

In light of poor practical conditions such a large number of Social issues will

\section{Rise like:}

\section{$>$ Poverty}

Destitution has been one of the most serious issues that Pakistan confronts today. It is rightly said that destitution anyplace is a danger to flourishing all over the place. As indicated by an investigation, neediness has expanded generally from $30 \%$ to $40 \%$ amid the previous decade. It implies that 40 for each penny of the nation's populace is simply gaining their job beneath the neediness line. In such condition individuals are denied of their essential necessities of life. Legitimate training and pharmaceutical are getting to be far off from them. They are compelled to think about their survival just.

\section{$>\quad$ Illiteracy}

The absence of education rate everywhere throughout the world is expanding and the prime reason adjacent to it is the high cost of instruction and absence of foundations and access. Individuals because of absence of assets can't instruct their kids' thus chain is produced.

\section{$>\quad$ Health Problem}


Wellbeing is another social issue created by poor efficient conditions. The typical cost for basic items is always expanding and deficiency of assets is a standard issue around the world. There are less doctor's facilities and restorative focuses and if there are any, the general population can't bear the cost of their and their youngsters wellbeing costs.

\section{$>\quad$ Over-Population}

Pakistan is confronting the monster of overpopulation. Since 1947, the populace has turned out to be more than triple. With constrained assets it is exceptionally hard to oblige the requirements of developing populace. There is an incredible monetary difference among the general population. Poor are submitting suicides out of yearning while rich are occupied in accumulating more riches.

\section{$>\quad$ Unemployment}

Unemployment is a noteworthy social issue brought on by poor sparing framework. Entire world is confronting difficult issues of unemployment and the explanation for it is the flimsy economy. Absence of assets took after by disorderly framework and absence of new tasks are bringing about unemployment around the world. In this way the serving of meriting individuals is not utilized, making misfortune both nation and the individual. In Pakistan real parcel of populace comprises of youth and an extensive number of youngsters who have the capacity and are willing to work are unemployed. As of now rate of unemployment according to authority assets is $7.4 \%$ however as indicated by some private gauges the rate of unemployment is $12 \%$.

\section{$>\quad$ Child Labor}

Youngster work is the most irritating thing that the kids which should instructed and gave everything their needs are compelled to do work particularly material science work which is exceptionally difficult site. Tyke work is the most genuine social conservative issue. The flow of cash is controlled to rich individuals just bringing on the poor to end up poorer. Whether in greater urban areas or in little towns, we discover blameless kids utilized in different types of work. They are filling in as welders.

\section{Conclusions:}

It is rightly said that destitution anyplace is a danger to flourishing all over the place. As indicated by an investigation, neediness has expanded generally from $30 \%$ to $40 \%$ amid the previous decade. It implies that 40 for each penny of the nation's populace is simply gaining their job beneath the neediness line. In such condition individuals are denied of their essential necessities of life. Legitimate training and pharmaceutical are getting to be far off from them. They are compelled to think about their survival just. Absence of assets took after by disorderly framework and absence of new tasks are bringing about unemployment around the world. In this way the serving of meriting individuals is not utilized, making misfortune both nation and the individual

\section{References}

1. Hamza Alvi. (2009). Pakistani women in a changing society Human Rights Commission of Pakistan - 1999 Report. Economic Survey of Pakistan, 10.

2. J.A. Rehman. (1998). The legal rights of women in Pakistan: Theory \& Practice, p.9. Nafisa Shah. (1993). Of Female Bondage. News time, January, p.44.

3. Nafisa Shah. (1998). A story in black: Karo Kari Killings in upper Sindh, REUTER Foundation Paper 100 ford 1998 p.5 Newsline, April, p.18.

4. Simi Kamal \& Asma Khan. (1997). A study of the interplay of formal and customary laws on woman, Vol. 1, p ii. Somnath Sen. (1992). 'Military Expenditure Data for Developing Countries: Methods and Measurement', in Geoffrey Lamb and Valeriana Kallab (ed.), Military Expenditure and Economic Development: A Symposium on Research Issues, Discussion Paper no.185, The World Bank, Washington, D.C. Notes Note 1. The UN Declaration on the Elimination of violence against women, General Assembly Resolution, December, 1993 Note 2.

5. Simi Kamal, Asma Khan: A study of the interplay of formal and customary laws on woman, Vvol 1, 1997, p ii Note 3.

6. Aman. S. Kitchen Murders: why only women? The News 20th June 1992 Note 4. Human Rights Commission of Pakistan: State of Human Rights in 2001 Note 5.

7. Human Development in South Asia 2000: The Gender Question Mebub-ul-Haq Human Development Center p.92 Note 6.

8. J.A. Rehman, The legal rights of women in Pakistan: Theory \& Practical, 1998, p.9 Note 7. Nafisa Shah: A story in black: Karo Kari Killings in upper Sindh, REUTER Foundation Paper 100 ford 1998 p.5 Note 8. Newsline, April 1998, p.18 